\title{
PENGARUH KEPEMIMPINAN DAN LINGKUNGAN KERJA FISIK TERHADAP SEMANGAT KERJA KARYAWAN PADA UNIVERSITAS PGRI PALEMBANG
}

\author{
Heryati *)
}

\begin{abstract}
This Research aim to to know leadership influence and environment work physical either through parsial and also by together with spirit of Job Employees University PGRI Palembang. This Research population is all officer of University of PGRI Palmbang amounting to 416 people, while sample taken to amount to 83 people with the technique of random sampling.

Instrument of data collecting used is enquette by using scale likert compiled by pursuant to construction embraced from various theory realized by into variable operational, while examination to research instrument conducted by passing validity test and test the reliabilitas. Analyse the data done by passing conditions test consisted of by the test normalitas using test kolmogorovsmirnov, test the homogeneity by using test of Chi Square and test the Linearity using One-Way Anova. Hypothesis Examination done to use the analysis of regresi and correlation.

Result of research indicate that (1) by parsial there are influence which are positive and signifikan between leadership hotly work University PGRI Palembang employees. (2) By parsial also there are influence which are positive and signifikan [among/between] environment work physical hotly work University PGRI Palembang employees. (3) By together or simultan there are influence which are positive and signifikan between environment and leadership work physical hotly work employees.
\end{abstract}

Kata kunci : leadership, environment work physical, Job Employees

\section{LATAR BELAKANG}

Masalah sumber daya manusia masih menjadi sorotan dan tumpuhan bagi perusahaan atau organisasi untuk tetap dapat bertahan di era globalisasi. Sumber daya manusia mempunyai peran utama dalam setiap kegiatan perusahaan. Walaupun didukung dengan sarana dan prasarana serta sumber dana yang berlebihan, tetapi tanpa dukungan sumber daya manusia yang andal kegiatan perusahaan tidak akan terselesaikan dengan baik. Hal ini menunjukkan bahwa sumber daya manusia merupakan kunci pokok yang harus diperhatikan dengan segala kebutuhannya. Sebagai kunci pokok, sumber daya manusia akan menentukan keberhasilan pelaksanaan kegiatan perusahaan. Tuntutan perusahaan untuk memperoleh, mengembangkan dan mempertahankan sumber daya manusia yang berkualitas semakin mendesak sesuai dengan dinamika lingkungan yang selalu berubah.
Sumber daya manusia sebagai penggerak organisasi banyak dipengaruhi oleh perilaku para pesertanya (partisipannya) atau aktornya. Keikutsertaan sumber daya manusia dalam organisasi diatur dengan adanya pemberian wewenang dan tanggung jawab. Merumuskan wewenang dan tanggung jawab yang harus dicapai karyawan dengan standar atau tolak ukur yang telah ditetapkan dan disepakati oleh karyawan dan atasan. Karyawan bersama atasan masing-masing dapat menetapkan sasaran kerja dan standar kinerja yang harus dicapai serta menilai hasil-hasil yang sebenarnya dicapai pada akhir kurun waktu tertentu.

Setiap pembicaraan tentang organisasi tentu tidak akan terlepas dari kepemimpinan. Sebuah organisasi dijalankan dan diatur oleh seorang pemimpin. Kepemimpinan merupakan usaha yang dijalankan untuk mempengaruhi anggota

*) Dosen Tetap Fakultas Ekonomi UPGRI Palembang 
kelompok agar mereka dengan suka rela menyumbangkan kemampuannya secara maksimal demi pencapain tujuan kelompok yang telah ditetapkan.

Teori-teori

tentang kepemimpinan telah banyak diteliti orang dengan maksud untuk mengetahui bagaimana sebenarnya kepemimpinan yang baik dan berhasil itu. Disamping itu teori-teori kepemimpinan dimaksud untuk mengetahui unsur-unsur apa saja yang membentuk pribadi seseorang sehingga diketahui sebagai seorang pemimpin yang disegani dan diikuti kepemimpinannya. Seluruh kepribadian tentang kepemimpinan telah dicoba untuk dianalisis seperti: keadaan fisik, kehidupan sosial, imajinasi, kesabaran, kejujuran, intelegensia, dan lain sebagainya.

Pemimpin yang ideal dituntut harus mampu mengenal identitas dirinya secara tepat dan benar. Selain itu pemimpin juga harus bisa memberikan dan menunjukkan keteladanan hidupnya. Lebih jauh lagi pemimpin diharuskan memiliki pengaruh bagi bawahannya atau anggotanya. Hal ini bukan merupakan suatu yang baru di era globalisasi dan komunikasi sekarang ini, tapi sudah menjadi hal lumrah dalam menjalani kehidupan. Salah satu contoh yang tidak bisa ditawartawar adalah pengaruh seorang pemimpin bagi semangat kerja karyawannya. Dengan kata lain, pemimpin harus menjadi corong, berdidak sebagai mercusuar yang selalu menerangi, menjadi tongkat penuntun, menjadi pelita bernyala dan bahkan mesti menjadi contoh bagi karyawannya.

Pemimpin dalam hal ini Rektor Universitas PGRI Palembang sangat perlu menerapkan hal tersebut karena pemimpin harus mampu menunjukkan sikap, sifat dan tingkah laku yang baik bagi bawahannya sehingga pemimpin mampu menjadi contoh tempat bertanya bahkan tempat mengeluh baik suka maupun duka bagi karyawan. Pada titik inilah seorang mendapat nilai utama skala prioritas, primus interpares, jalan bagi karyawannya dalam dan untuk bekerja. Dengan demikian karyawan merasa lebih bersemangat dalam bekerja, bertanggungjawab terhadap hasil kerjanya dan bersikap loyal terhadap organisasi sehingga tujuan organisasi dapat tercapai.

Di lain pihak kondisi lingkungan kerja fisikpun sangat berpengaruh terhadap semangat kerja karyawan. Lingkungan kerja fisik merupakan suatu lingkungan dimana para karyawan bekerja dan dapat mempengaruhi mereka dalam menjalankan tugas-tugas yang dibebankan. Faktor-faktor yang termasuk lingkungan kerja fisik adalah pewarnaan, kebersihan, pertukaran udara, penerangan, musik, kebisingan dan ruang gerak.

Lingkungan kerja fisik yang baik akan memberikan kenyamanan pribadi maupun dalam membangkitkan semangat kerja karyawan sehingga dapat mengerjakan tugas-tugas dengan baik. Faktor lingkungan kerja fisik yang lainnya juga perlu diperhatikan. Disamping itu karyawan akan lebih senang dan nyaman dalam bekerja apabila fasilitas yang ada dalam keadaan bersih, tidak bising, pertukaran udara yang cukup baik dan peralatan yang memadai serta relatif modern.

Lingkungan kerja yang nyaman dan sarana-sarana pendukung yang memadai adalah salah satu faktor yang sangat dibutuhkan pegawai dalam menjalankan pekerjaannya. Walaupun lingkungan kerja termasuk 
salah satu faktor yang penting dalam meningkatkan semangat kerja, tetapi masih banyak organsasi atau perusahaan yang belum begitu memperhatikannya.

Universitas PGRI Palembang sebagai salah satu universitas yang bergerak dibidang pendidikan. Dalam rangka menghadapi tantangan dan tugas-tugas masa depan tidak terlepas dari peran aktif tenaga kerja atau karyawan yang memiliki kemampuan, kreativitas, inovatif dan bertanggung jawab dalam melaksanakan pekerjaannya berupaya mewujudkan sistem dan iklim pendidikan yang baik.

Kondisi yang ada saat ini menunjukkan bahwa masih kurangnya sarana dan prasarana sebagai pendukung yang sangat dibutuhkan pegawai dalam menjalankan pekerjaannya dan kurangnya perhatian pimpinan terhadap lingkungan kerja fisik hal ini berimplikasi dalam semangat kerja karyawan.

Kondisi-kondisi diatas menarik minat penulis untuk melakukan penelitian dengan judul Pengaruh kepemimpinan dan lingkungan kerja fisik terhadap semangat kerja karyawan Universitas PGRI Palembang."

\section{Perumusan Masalah}

Berdasarkan latar belakang masalah di atas maka dapat dirumuskan masalah sebagai berikut:

1. Apakah terdapat pengaruh kepemimpinan terhadap semangat kerja karyawan Universitas PGRI Palembang?

2. Apakah terdapat pengaruh lingkungan kerja fisik terhadap semangat kerja karyawan Universitas PGRI Palembang?

3. Apakah terdapat pengaruh kepemimpinan dan lingkungan kerja fisik terhadap semangat kerja karyawan Universitas PGRI Palembang?

\section{KERANGKA TEORITIS}

\section{A. Semangat Kerja}

1. Pengertian Semangat Kerja

Semangat kerja pada hakekatnya adalah merupakan perwujudan dari moral yang tinggi. Bahkan ada yang mengidentikan atau menterjemahkan secara bebas, moral kerja yang tinggi adalah semangat dan kegairahan kerja. Semangat kerja karyawan merupakan masalah yang penting dalam setiap usaha kerjasama kelompok orang dalam mencapai tujuan tertentu dari kelompok tersebut.

Menurut Nitisemito (2002 :

108) semangat kerja adalah melakukan pekerjaan secara lebih giat dengan jalan memperkecil kekeliruan dalam pekerjaan, mempertebal rasa tanggung jawab, serta dapat menyelesaikan tugas tapi waktunya sesuai dengan rencana yang ditetapkan. Semangat (moril) kerja adalah kemampuan sekelompok orangorang untuk bekerja sama dengan giat dan konsekuen dalam mengejar tujuan bersama (Moekijat, 2002 : 130).

Definisi

di atas

menunjukkan bahwa dengan meningkatnya semangat dan kegairahan kerja, maka pekerjaan akan lebih cepat dapat diselesaikan, kerusakan akan dapat dikurangi, absensi akan dapat diperkecil sehingga dengan ini semua produktivitas akan dapat ditingkatkan. 
2. Faktor-faktor yang mempengaruhi semangat kerja karyawan

Ada beberapa faktor yang dapat mempengaruhi tinggi rendahnya semangat kerja karyawan, yaitu antara lain:

a. Gaji yang cukup

$$
\text { Setiap perusahaan }
$$

seharusnya memberikan gaji yang cukup kepada karyawan/pegawainya.

Pengertian "cukup" ini adalah sebenarnya sangat relatif sifatnya. Oleh karena itu cukup di sini adalah jumlah yang mampu dibayar tanpa menimbulkan kerugian bagi perusahaan tersebut. Dan dengan sejumlah gaji yang diberikan tersebut akan mampu memberikan kegairahan kerja para pegawainya.

b. Memperhatikan kebutuhan rohani

Selain kebutuhan materi yang berbentuk gaji yang cukup, mereka juga membutuhkan kebutuhan rohani. Kebutuhan rohani ini antara lain adalah menyediakan tempat untuk menjalankan ibadah, rekreasi, partisipasi dan sebagainya.

c. Sekali-kali perlu menciptakan suasana santai

Suasana kerja yang rutin sering kali menimbulkan kebosanan dan ketegangan kerja bagi karyawan. Untuk menghindari hal-hal seperti itu maka perusahaan perlu sekali kadang-kadang (dalam kurun waktu tertentu) menciptakan suasana santai.

d. Harga diri perlu mendapat perhatian
Perusahaan yang baik biasanya mempunyai karyawan yang hasil kerjanya dapat diandalkan. Dengan keadaan seperti itu perusahaan akan cepat maju karena cara kerja karyawan cukup baik.

e. Tempatkan para karyawan/pegawai pada posisi yang tepat

Setiap perusahaan harus mampu menempatkan para karyawannya pada posisi yang tepat. Artinya tempatkan mereka pada posisi yang sesuai dengan keterampilan masing-masing. Jadi sesungguhnya masalah ketepatan menempatkan para karyawan pada posisi yang telah merupakan salah satu faktor yang sangat penting dalam usaha membangkitkan kegairahan kerja karyawan.

f. Berikan kesempatan untuk maju

Kegairahan kerja karyawan akan timbul jika mereka mempunyai harapan untuk maju. Jika hendaknya setiap perusahaan memberikan kesempatan kepada karyawannya. Berikanlah penghargaan kepada karyawan yang berprestasi.

g. Perasaan aman menghadapi masa depan perlu diperhatikan

Kegairahan kerja para karyawan akan terpupuk jika mereka mempunyai perasaan aman terhadap masa depan profesi mereka. Untuk menciptakan rasa aman menghadapi masa depan, ada sementara 


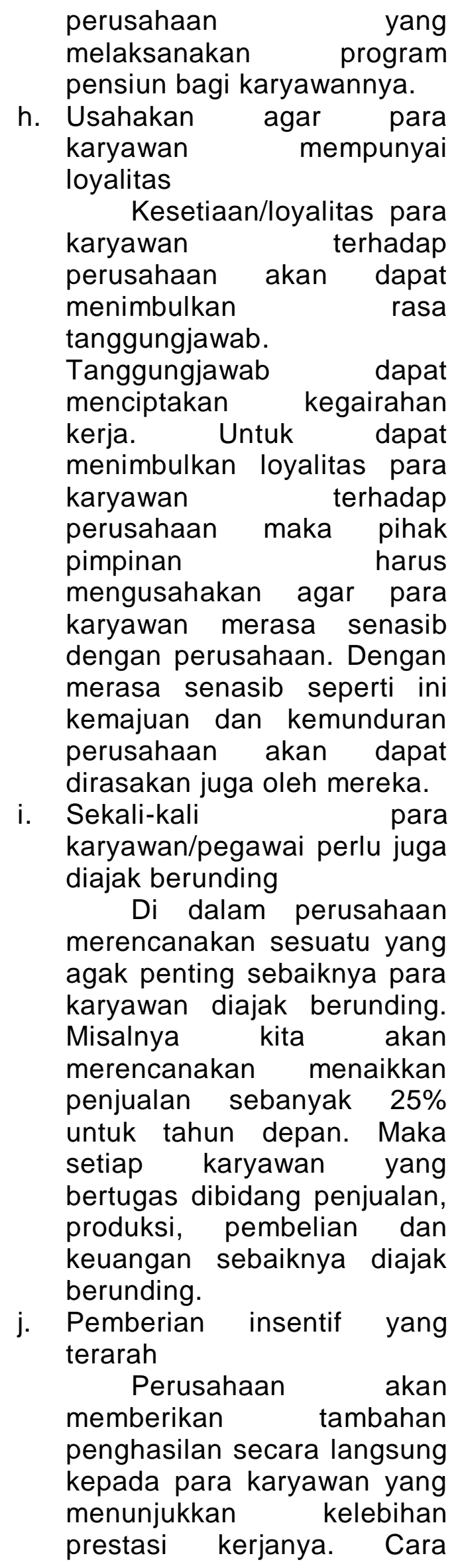

seperti ini sangat efektif untuk mendorong gairah kerja para karyawan. Tentu saja cara itu harus juga disertai dengan kebijaksanaan yang tepat.

k. Fasilitas yang menyenangkan

Setiap perusahaan bila mana memungkinkan hendaknya menyediakan fasilitas yang menyenangkan bagi para karyawan. Apabila dengan fasilitas tersebut ternyata mampu menambah kesenangan pada karyawannya maka berarti kegairahan kerjanya dapat pula ditingkatkan.

\section{B. Kepemimpinan}

1. Pengertian Kepemimpinan

Suatu organisasi akan berhasil atau bahkan gagal sebagian besar ditentukan oleh kepemimpinan. Seorang pemimpinlah yang bertanggungjawab atas kegagalan pelaksanaan suatu pekerjaan, merupakan suatu ungkapan yang mendudukan posisi pemimpin dalam suatu organisasi pada posisi yang terpenting dan akan selalu mempertanggungjawabkan

kepemimpinannya (Thoha, 2003 : 1).

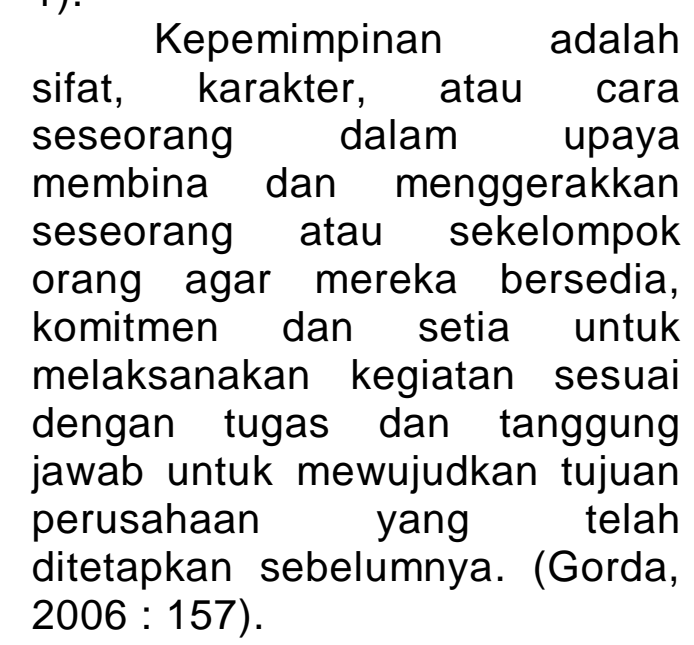


Kepemimpinan adalah suatu proses penggunaan pengaruh positif terhadap orang lain untuk melakukan usaha lebih banyak dalam sejumlah tugas atau mengubah perilakunya (Wexley dan Yuki, $2003: 189$ ).

Dari pengertian beberapa ahli tersebut dapat dikatakan kepemimpinan adalah sifat atau karakter, atau kegiatan atasan atau pimpinan untuk mempengaruhi perilaku sekelompok karyawan secara positif, membimbing dan mengarahkannya agar bekerja dengan lancar sehingga tujuan perusahaan dapat tercapai dengan baik.

2. Indikator Kepemimpinan

Berdasarkan pendapat dari Riduan (2002,h.26) membagi kepemimpinan menjadi 5 ( lima) yaitu :

a. Kepemimpinan sebagai fungsi pembina.

b. Kepemimpinan sebagai teknik menciptakan hubungan timbal balik.

c. Kepemimpinan sebagaiu teladan.

d. Kepemimpinan sebagai seni pembinaan perintah.

e. Kepemimpinan sebagai pengguna komunikasi.

Dari beberapa pendapat para ahli di atas, maka dapat ditarik kesimpulan bahwa kepemimpinan adalah yang mempunyai kemampuan untuk mempengaruhi oang lain dan menggerakkan bawahan sedemikian rupa sehingga dapat memberikan pembinaan, keteladanan, perintah terhadap karyawan agar mau bekerja dalam rangka mencapai tujuan organisasi.
C. Lingkungan Kerja Fisik

1. Pengertian lingkungan kerja fisik Lingkungan kerja fisik adalah keseluruhan atau setiap aspek dari gejala fisik dan sosialkultural yang mengelilingi atau mempengaruhi individu. (Komarudin, 2002 : 142).

Lingkungan kerja fisik adalah segala sesuatu yang ada di sekitar para pekerja yang dapat mempengaruhi dirinya dalam menjalankan tugas-tugas yang dibebankan, misalnya penerangan, suhu udara, ruang gerak, keamanan, kebersihan, musik dan lain-lain (Nitisemito, 2002 : 183).

tersebut dapat dinyatakan lingkungan kerja fisik adalah segala sesuatu yang ada di sekitar karyawan bekerja yang mempengaruhi karyawan dalam melaksanakan beban tugasnya. Masalah lingkungan kerja dalam suatu organisasi sangatlah penting, dalam hal ini diperlukan adanya pengaturan maupun penataan faktor-faktor lingkungan kerja fisik dalam penyelenggaraan aktivitas organisasi.

2. Faktor-faktor lingkungan kerja fisik

Lingkungan kerja fisik adalah segala sesuatu yang ada di sekitar para pekerja yang dapat mempengaruhi dirinya didalam melaksanakan tugastugasnya. Faktor-faktor lingkungan kerja fisik adalah sebagai berikut :
a. Pewarnaan
b. Penerangan
c. Udara
d. Suara bising 
e. Ruang gerak

f. Keamanan

g. Kebersihan

\section{Kerangka Pemikiran}

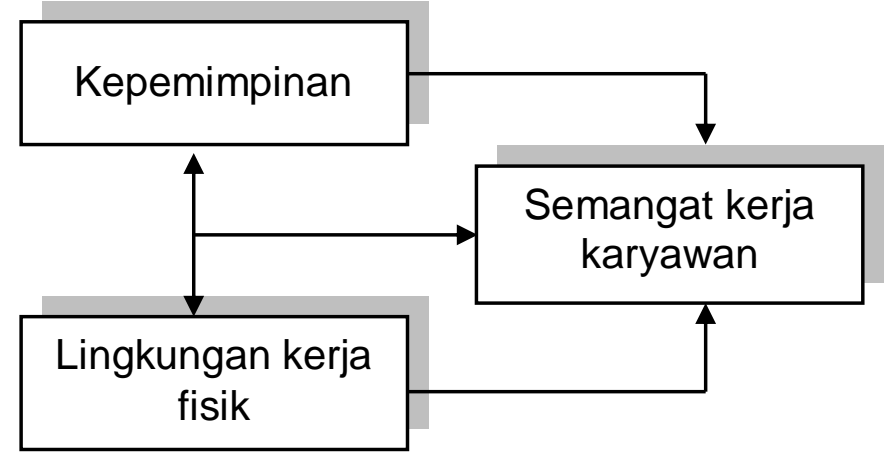

Gambar 1. Kerangka Pemikiran Penelitian

\section{E. Hipotesis Penelitian}

Dari teori dan kerangka pemikiran penelitian yang dikemukakan di atas, maka diambil dugaan sementara atau hipotesis sebagai berikut:

1. Diduga kepemimpinan mempunyai pengaruh positif dan signifikan terhadap semangat kerja karyawan Universias PGRI Palembang.

2. Diduga lingkungan kerja fisik mempunyai pengaruh positif dan signifikan terhadap semangat kerja karyawan Universias PGRI Palembang.

3. Diduga kepemimpinan dan lingkungan kerja fisik mempunyai pengaruh yang signifikan terhadap semangat kerja karyawan Universias PGRI Palembang.

\section{METODE PENELITIAN}

\section{A. Rancangan / Model Umum Penelitian}

Penelitian ini adalah survey kuantitatif dengan pendekatan deskriptif. Landasan pemikiran penetapan pendekatan deskriptif adalah bahwa informasi yang diharapkan diperoleh adalah tentang gejala pada saat penelitian dilakukan. Rancangan penelitian ini terdiri atas variabel terikat, yaitu semangat kerja kayaran $(Y)$, variabel bebas, yaitu, kepemimpinan $\left(X_{1}\right)$, dan lingkungan kerja fisik $\left(\mathrm{X}_{2}\right)$.

\section{B. Populasi dan Teknik Sampling} Menurut Sugiyono (2008 : 115) populasi adalah wilayah generalisasi yang terdiri atas obyek/subyek yang mempunyai kuantitas dan karakteristik tertentu yang diterapkan oleh peneliti untuk dipelajari dan kemudian ditarik kesimpulannya. Adapun populasi dalam penelitian ini adalah seluruh pegawai tetap Universitas PGRI Palembang yang berjumlah 416 orang.

Dalam penelitian ini tehnik pengambilan sample yang dilakukan secara stratified sampling selanjutnya ditarik secara random dengan menggunakan metode simple random sampling atau pengambilan secara acak sederhana. Menurut Arikunto apabila populasi dibawah 100, sebaiknya diambil semua, apabila populasi di atas 100, sebaiknya diambil $10-15 \%$ atau $20-25 \%$ atau lebih. Berdasarkan pendapat tersebut maka besarnya sampel yang diambil $20 \%$ dari jumlah populasi yaitu sebanyak 83 orang, dengan rincian 33 orang digunakan untuk uji coba instrumen dan 50 orang untuk sampel data.

\section{Definisi Operasional Variabel}

1. Semangat Kerja Karyawan

Semangat kerja karyawan, adalah sikap mental dari individu maupun kelompok yang menunjukkan kesungguhannya 
di dalam melaksanakan pekerjaan sehingga mendorong untuk bekerja lebih baik yang ditunjukkan. Semangat kerja karyawan dalam penelitian ini diukur dari: gaji yang cukup, memperhatikan kebutuhan rohani, sekali-kali perlu menciptakan suasana santai, harga diri perlu mendapat perhatian, tempatkan para karyawan/pegawai pada posisi yang tepat, berikan kesempatan untuk maju, perasaan aman menghadapi masa depan perlu diperhatikan, usahakan agar para karyawan mempunyai loyalitas, sekali-kali para karyawan/pegawai perlu juga diajak berunding, dan pemberian insentif yang terarah.

\section{Kepemimpinan}

Kepemimpinan, adalah kemampuan yang dimiliki oleh tiap-tiap pemimpin untuk menggerakkan orang lain dengan memimpin, membimbing, mengawasi, memberikan contoh, dan mengarahkan orang lain untuk bekerja dengan baik sehingga tujuan perusahaan dapat tercapai. Kepemimpinan dalam penelitian ini diukur dari pembinaan, teladan, memberi perintah, memotivasi bawahan sedemikian rupa melalui berbagai aktivitas yang dilakukan sehingga mau bekerja dengan bergairah dan bersedia bekerja sama untuk mencapai suatu tujuan.

\section{Lingkungan Kerja Fisik}

Lingkungan kerja fisik, adalah segala sesuatu yang ada di sekitar karyawan. Lingkungan kerja fisik dalam penelitian ini diukur dari : pewarnaan, penerangan, udara, suara bising, ruang gerak, keamanan dan kebersihan.

\section{Teknik Pengujian Instrumen}

1. Uji Validitas

Untuk mengukur validitas instrumen kepemimpinan, lingkungan kerja fisik dan semangat kerja karyawan dilakukan ujicoba instrumen dengan menggunakan pegawai sebagai responden. Validitas instrumen ke tiga variable dicari dengan cara menghitung data dengan rumus Pearson Product Moment dalam program SPSS.

\section{Uji Reliabilitas}

Untuk pengujian reliabilitas ketiga instrumen kepemimpinan, lingkungan kerja fisik dan semangat kerja karyawan dilakukan dengan metode internal consistency dengan teknik belah dua (spilt half) dari Spearman Brown. Langkah pertama, setelah dilakukan uji coba dan ditemukan validitasnya, item-item yang valid dikumpulkan, dan item yang tidak valid dibuang. Langkah kedua, item-item yang valid dibelah menjadi dua secara acak, dilakukan penskoran tiap item masing-masing kelompok sehingga ditemukan skor total tiap belahan. Langkah ketiga, dilakukan korelasi antara jumlah skor belahan awal dan belahan akhir.

\section{Uji Normalitas}

Untuk melakukan uji normalias distribusi data, menurut (Santoso, 2004, h. 36) dapat digunakan uji Kolmogorof-Smirnov dari program SPSS. Normalitas distribusi data dihitung dengan cara membandingkan nilai Asymtotic Signivicance yang 
diperoleh dengan nilai $\alpha=0,05$. Apabila Asymp. Sig $>\alpha=0,05$, maka data dinyatakan normal.

\section{Uji Homogenitas}

Sebagai salah satu persyaratan untuk melakukan analisis data dengan menggunakan analisis regresi, data perla diuji homogenitasnya. Uji homogenitas ini perlu untuk memastikan apakah data tersebut berasal dari populasi yang homogen. Pengujian homogenitas pada penelitian ini dilakukan dengan menggunakan $\mathrm{Uji}$ ChiSquare dengan menetapkan signifikansi $5 \% \quad(\alpha=0,05)$. Interpretasi homogenitas data dihitung berdasarkan nilai Asymtotic significance yang diperoleh. Jika Asymp. Sig. $>\alpha=$ 0,05 , maka data dinyatakan homogen.

\section{Uji Linearitas}

Uji linearitas dipergunakan untuk mengetahui apakah regresi yang diperoleh "berarti" apabila dipergunakan untuk membua kesimpulan antar variable yang sedang dianalisis. Pengujian linearitas variable bebas dengan variable terikat dilakukan dengan menggunakan One-Way Anova program SPSS. Pengujian linearitas menggunakan taraf signifikansi $5 \% \quad(\alpha=0,05)$. Interpretasi datas dilakukan dengan ketentuan Jika $\mathrm{F}_{\text {-hitung }}<\mathrm{F}$ tabel, maka variabel bebas dengan variabel terikat tersebut mempunyai hubungan yang linear.

\section{E. Teknik Analisis Data}

1. Analisis Regresi Berganda

Analisis regresi pada dasarnya adalah studi mengenai ketergantungan variabel terikat dengan satu atau lebih variabel bebas dengan tujuan untuk memprediksi nilai rata-rata variabel terikat berdasarkan nilai variabel bebas yang diketahui (Gozhali, 2001:43).

Persamaan garis regresi linier berganda dapat ditulis sebagai berikut:

$$
Y=a+b_{1} X_{1}+b_{2} X_{2}+e
$$

Dimana :

$Y=$ Semangat kerja karyawan

$\mathrm{a}=$ Nilai konstanta

$X_{1}=$ Kepemimpinan

$\mathrm{X}_{2}=$ Lingkungan Kerja Fisik

$b_{1}=$ Koefisien regresi dari $X_{1}$

$b_{2}=$ Koefisien regresi dari $X_{2}$

$\mathrm{e}=$ Stándar error of the estímate

\section{Analisis Korelasi Berganda}

Analisis ini digunakan untuk mengetahui derajat hubungan antara variable kepemimpinan $\left(X_{1}\right)$ dan lingkungan kerja fisik $\left(X_{2}\right)$ dengan variabel semangat kerja karyawan $(\mathrm{Y})$, dengan rumus:

$$
\mathrm{R}=\sqrt{\frac{b_{1} \sum x_{1} y+b_{1} \sum x_{2} y}{\sum y}}
$$

Kriteria yang digunakan untuk menentukan tinggi rendahnya hubungan yang terjadi antara variabel sebagai berikut (Riduwan, $2005: 228)$ :
$0,00-0,199=$ Sangat rendah
$0,20-0,399=$ Rendah
$0,40-0,599=$ Cukup
$0,60-0,799=$ Kuat
$0,80-1,000=$ Sangat Kuat

\section{Analisis Determinasi}

Analisis ini digunakan untuk mengetahui variasi hubungan variabel terikat yang disebabkan oleh variabel bebas dengan rumus sebagai berikut (Riduwan, 2005 : 228) : 
$D=R^{2} \cdot 100 \%$

Dimana :

$\mathrm{D}=$ Koefisien Determinasi

$\mathrm{R}=$ koefisien korelasi multiple

\section{F. Uji Hipotesis}

Pengujian hipotesis dalam penelitian ini adalah Uji $t$ dipergunakan untuk mengetahui pengaruh antara variabel kepemimpinan $\left(X_{1}\right)$ dan lingkungan kerja fisik $\left(X_{2}\right)$ dengan semangat kerja karyawan $(Y)$ secara parsial. Uji $F$ dipergunakan untuk menguji nyata tidaknya pengaruh variabel bebas secara Simultan terhadap variabel terkait (Imam Ghozali, 2001 : 46).

\section{HASIL PENELITIAN DAN PEMBAHASAN}

\section{A. PENGUJIAN INSTRUMEN}

\section{Uji Validitas}

Dari hasil perhitungan untuk variabel semangat kerja dari 23 butir pertanyaan diperoleh nilai $r$ hitung lebih besar dari $r$ tabel 0,279 (tabel $r$ Product Moment) sehingga dinyatakan semua pertanyaan dinyatakan valid. Untuk penelitian sebenarnya variabel semangat kerja menggunakan semua butir pernyataan.

Dari hasil perhitungan untuk variabel kepemimpinan dari 20 butir pertanyaan diperoleh nilai $r$ hitung lebih besar dari $r$ tabel 0,279 (tabel $r$ Product Moment) sehingga dinyatakan semua pertanyaan dinyatakan valid. Untuk penelitian sebenarnya variabel kepemimpinan menggunakan semua butir pernyataan.

Dari hasil perhitungan di atas untuk variabel lingkungan kerja fisik dari 20 butir pertanyaan diketahui butir pertanyaan nomor 7 memiliki nilai $r$ hitung 0,248 lebih kecil dari $r$ tabel 0,279 , sehingga dinyatakan tidak valid dan di buang dari kuesioner. Untuk penelitian sebenarnya variabel lingkungan kerja fisik menggunakan 19 butir pernyataan.

\section{Uji Reliabilitas}

Dari perhitungan melalui program SPSS untuk variabel semangat kerja didapatkan nilai korelasi antara skor item ganjil dengan item genap adalah 0.830 . Korelasi ini memiliki tingkat signifikansi yang tinggi. Tanda bintang dua menunjukkan bahwa korelasi signifikan pada alpha $0,01 \%$. Dengan demikian, dapat dikatakan bahwa item-item pada instrumen diatas memiliki tingkat reliabilitas yang cukup tinggi. Artinya, instrumen penelitian yang dihasilkan sangat reliable. Sehingga dapat disimpulkan bahwa instrumen semangat kerja lolos uji reliabilitas.

$$
\text { Untuk }
$$

variabel kepemimpinan didapatkan nilai korelasi antara skor item ganjil dengan item genap adalah 0.935 . Korelasi ini memiliki tingkat signifikansi yang sangat tinggi. Tanda bintang dua menunjukkan bahwa korelasi signifikan pada alpha $0,01 \%$. Dengan demikian, dapat dikatakan bahwa item-item pada instrumen diatas memiliki tingkat reliabilitas yang tinggi. Artinya, instrumen penelitian yang dihasilkan sangat reliable. Sehingga dapat disimpulkan bahwa instrumen kepemimpinan Iolos uji reliabilitas.

Sedangkan variabel lingkungan kerja Dari output di atas didapatkan nilai korelasi antara skor item ganjil dengan item genap adalah 0.716 . Korelasi ini 
memiliki tingkat signifikansi yang sangat tinggi. Tanda bintang dua menunjukkan bahwa korelasi signifikan pada alpha 0,01\%. Dengan demikian, dapat dikatakan bahwa item-item pada instrumen diatas memiliki tingkat reliabilitas yang tinggi. Artinya, instrumen penelitian yang dihasilkan reliable. Sehingga dapat disimpulkan bahwa instrumen lingkungan kerja fisik lolos uji reliabilitas.

B. UJI PERSYARATAN ANALISIS

1. Uji Normalitas

$\begin{array}{ccc}\text { Uji } & \text { normalitas } & \text { dilakukan } \\ \text { terhadap } & \text { seluruh } & \text { variabel }\end{array}$
penelitian untuk mengetahui apakah data populasi tersebut berdistribusi normal atau tidak. Pengujian persyaratan ini dilakukan dengan menggunakan uji Kolmogorov Smirnov. Dalam penelitian ini, taraf signifikansi yang digunakan adalah $5 \%$ atau $\alpha$ $=0.05$, jadi $\mathrm{H}_{\mathrm{o}}$ diterima jika Asymp. Signifikansi lebih besar dari 0.05 dan $\mathrm{H}_{0}$ ditolak Asymp. Signifikansi lebih kecil dari 0.05 .

Dari hasil perhitungan diperoleh Asymp. Signifikansi untuk ketiga variabel di atas masing-masing sebesar 0,945, 0,407 dan 0,460 lebih besar dari 0.05, maka $\mathrm{H}_{0}$ diterima, artinya hasil pengujian menunjukkan data untuk ketiga variabel di atas berdistribusi normal.

\section{Uji Homogenitas}

Pengujian homogenitas pada penelitian ini dilakukan dengan menggunakan Uji Chi-Square dengan menetapkan signifikansi $5 \% \quad(\alpha=0,05)$. Interpretasi homogenitas data dihitung berdasarkan nilai Asymtotic significance yang diperoleh. Jika
Asymp. Sig. $>\alpha=0,05$, maka data dinyatakan homogen.

Dari hasil perhitungan diperoleh Asymp. Signifikansi untuk ketiga variabel di atas masing-masing sebesar 0,987, 0,910 dan 0,749 lebih besar dari 0.05, maka dapat disimpulkan bahwa data populasi untuk ketiga variabel di atas memiliki varians homogen.

\section{Uji Linieritas}

Pengujian linieritas bertujuan untuk mengetahui apakah terjadi penyimpangan linieritas atau tidak. Jika terjadi penyimpangan linieritas maka analisis yang digunakan adalah regresi non linier.

a. Hubungan Semangat Kerja (Y) dengan Kepemimpinan (X1)

Dari hasil perhitungan uji linieritas antara semangat kerja dengan kepemimpinan diperoleh nilai deviation from linearity sebesar 0,367 , nilai yang diperoleh lebih besar dari $\alpha$ sebesar $5 \%$, maka $\mathrm{H}_{0}$ diterima artinya variabel semangat kerja dengan kepemimpinan mempunyai hubungan yang linier.

b. Hubungan Semangat Kerja (Y) dengan Lingkungan Kerja Fisik (X2)

Dari hasil perhitungan uji linieritas antara semangat kerja dengan lingkungan kerja fisik diperoleh nilai sebesar 0,890 , nilai yang diperoleh lebih besar dari $\alpha$ sebesar $5 \%$, maka $\mathrm{H}_{0}$ diterima artinya variabel semangat kerja dengan lingkungan kerja fisik mempunyai hubungan yang linier. 


\section{UJI ANALISIS REGRESI}

1. Pengaruh kepemimpinan $\left(\mathrm{X}_{1}\right)$ terhadap semangat kerja $(\mathrm{Y})$

Tabel 1

Analisis Regresi Variabel $\left(\mathrm{X}_{1}\right)$ dan $(\mathrm{Y})$

\begin{tabular}{|ll|r|r|r|r|r|}
\hline \multirow{2}{*}{ Model } & & \multicolumn{2}{|c|}{$\begin{array}{l}\text { Unstandardized } \\
\text { Coefficients }\end{array}$} & $\begin{array}{c}\text { Standardized } \\
\text { Coefficients }\end{array}$ & $\mathrm{t}$ & Sig. \\
\cline { 3 - 7 } & \multicolumn{1}{c|}{$\mathrm{B}$} & Std. Error & Beta & & \\
\hline 1 & (Constant) & 37,749 & 9,143 & & 4,129 &, 000 \\
& Kepemimpinan (X1) &, 653 &, 117 &, 626 & 5,567 &, 000 \\
\hline
\end{tabular}

Dari hasil perhitungan melalui program SPSS di atas, diperoleh nilai koefisien regresi untuk constanta $=37,749$ dan koefisien kepemimpinan = 0,653 . Sehingga persamaan regresi dapat dituliskan sebagai berikut : $\hat{Y}=37,749+0,653 X_{1}$

$$
+e
$$

Dimana :

- Konstanta sebesar 37,749 menyatakan bahwa jika tidak ada kepemimpinan maka skor semangat kerja adalah 37,749.

- Koefisien regresi $X_{1}$ sebesar 0,653 menyatakan bahwa setiap penambahan satu satuan skor kepemimpinan akan meningkatkan skor semangat kerja sebesar 0,653 .

2. Pengaruh lingkungan kerja fisik $\left(\mathrm{X}_{2}\right)$ terhadap semangat kerja $(\mathrm{Y})$

Tabel 2

Analisis Regresi Variabel $\left(\mathrm{X}_{2}\right)$ dan $(\mathrm{Y})$

\begin{tabular}{|ll|r|r|r|r|r|}
\hline \multirow{2}{*}{ Model } & \multicolumn{2}{|c|}{$\begin{array}{c}\text { Unstandardized } \\
\text { Coefficients }\end{array}$} & $\begin{array}{c}\text { Standardized } \\
\text { Coefficients }\end{array}$ & \multicolumn{1}{c|}{ t } & Sig. \\
\cline { 2 - 7 } & \multicolumn{1}{c|}{$\mathrm{B}$} & Std. Error & \multicolumn{1}{c|}{ Beta } & & \\
\hline $1 \quad$ (Constant) & 31,312 & 8,300 & & 3,772 &, 000 \\
& Lingkungan Kerja &, 769 &, 111 &, 706 & 6,913 &, 000 \\
\hline
\end{tabular}

Dari hasil perhitungan melalui program SPSS di atas, diperoleh nilai koefisien regresi untuk constanta $=31,312$ dan koefisien lingkungan kerja fisik = 0,769 . Sehingga persamaan regresi dapat dituliskan sebagai berikut : $\hat{Y}=31,312+0,769 X_{1}$

$$
+e
$$

Dimana :

- Konstanta sebesar 31,312 menyatakan bahwa jika tidak ada lingkungan kerja fisik maka skor semangat kerja adalah 31,312.

- Koefisien regresi $X_{2}$ sebesar 0,769 menyatakan bahwa setiap penambahan satu satuan skor lingkungan kerja fisik akan meningkatkan skor semangat kerja sebesar 0,769 . 
3. Pengaruh kepemimpinan $\left(X_{1}\right)$ dan lingkungan kerja fisik $\left(X_{2}\right)$ terhadap semangat kerja $(Y)$

Tabel 3

Analisis Regresi Variabel $\left(\mathrm{X}_{1}\right),\left(\mathrm{X}_{2}\right)$ dan $(\mathrm{Y})$

\begin{tabular}{|c|c|c|c|c|c|c|}
\hline \multirow{2}{*}{\multicolumn{2}{|c|}{ Model }} & \multicolumn{2}{|c|}{$\begin{array}{l}\text { Unstandardized } \\
\text { Coefficients }\end{array}$} & \multirow{2}{*}{$\begin{array}{c}\text { Standardize } \\
d \\
\text { Coefficients } \\
\text { Beta } \\
\end{array}$} & \multirow[t]{2}{*}{$\mathrm{t}$} & \multirow[t]{2}{*}{ Sig. } \\
\hline & & B & Std. Error & & & \\
\hline \multirow[t]{3}{*}{1} & (Constant) & 19,327 & 8,720 & & 2,216 & ,032 \\
\hline & Kepemimpinan (X1) & ,351 & ,119 & ,337 & 2,940 & ,005 \\
\hline & $\begin{array}{l}\text { Lingkungan Kerja Fisik } \\
(\mathrm{X} 2)\end{array}$ & & ,125 & ,518 & 4,525 & ,000 \\
\hline
\end{tabular}

Dari hasil perhitungan melalui program SPSS di atas, diperoleh nilai koefisien regresi untuk constanta $=19,327$, koefisien kepemimpinan $=0,351$ dan koefisien lingkungan kerja fisik = 0,564. Sehingga persamaan regresi berganda dapat dituliskan sebagai berikut $\hat{\gamma}$

$\hat{Y}=19,327+0,351 X_{1}+0,564$ $X_{2}+e$

Dimana :

- Konstanta sebesar 19,327 menyatakan bahwa jika mengabaikan kepemimpinan dan lingkungan kerja fisik maka skor semangat kerja adalah 19,327.

- Koefisien regresi $X_{1}$ sebesar 0,351 menyatakan bahwa setiap penambahan satu satuan skor kepemimpinan akan meningkatkan skor semangat kerja sebesar 0,351 dengan menjaga skor lingkungan kerja fisik $\left(\mathrm{X}_{2}\right)$ tetap/konstan.

- Koefisien regresi $X_{2}$ sebesar 0,564 menyatakan bahwa setiap penambahan satu satuan skor lingkungan kerja fisik akan meningkatkan skor semangat kerja sebesar 0,564 dengan menjaga skor kepemimpinan tetap/konstan.

$\left(\mathrm{X}_{1}\right)$

\section{UJI ANALISIS KORELASI}

Koefisien korelasi ini untuk mengukur seberapa besar tingkat keeratan hubungan atau asosiasi yang terjadi antara baik variabel bebas secara parsial maupun variabel bebas secara bersamasama dengan variabel terikat. Menurut Haryono (2007 : 191), nilai koefisien korelasi dapat diinterpretasikan sebagai berikut :

Tabel 4

Interpretasi Koefisien Korelasi

\begin{tabular}{|c|c|}
\hline $\begin{array}{c}\text { Koefisien } \\
\text { Korelasi }\end{array}$ & Interpretasi \\
\hline 0 & Tidak ada korelasi \\
\hline $0,00<r \leq 0,25$ & Korelasi sangat lemah \\
\hline $0,25<r \leq 0,50$ & Korelasi lemah \\
\hline $0,50<r \leq 0,75$ & Korelasi kuat \\
\hline $0,75<r<1,00$ & Korelasi sangat kuat \\
\hline 1 & Korelasi sempurna \\
\hline
\end{tabular}


1. Hubungan kepemimpinan $\left(\mathrm{X}_{1}\right)$ dengan semangat kerja $(\mathrm{Y})$

Tabel 5

Analisis Korelasi Variabel $\left(\mathrm{X}_{1}\right)$ dan $(\mathrm{Y})$

\begin{tabular}{|l|c|c|c|c|}
\hline Model & $\mathrm{R}$ & $\mathrm{R}$ Square & $\begin{array}{c}\text { Adjusted R } \\
\text { Square }\end{array}$ & $\begin{array}{c}\text { Std. Error of the } \\
\text { Estimate }\end{array}$ \\
\hline 1 &, $626(\mathrm{a})$ &, 392 &, 380 & 7,121 \\
\hline
\end{tabular}

Berdasarkan hasil

perhitungan melalui program SPSS dapat di intepretasikan sebagai berikut :

- Pada Model Summary diperoleh nilai $R=0,626$ yang berarti bahwa hubungan atau tingkat asosiasi variabel bebas yaitu kepemimpinan dengan variabel terikat yaitu semangat kerja adalah kuat dan memiliki arah yang positif.
- Angka $R$ Square (nilai koefisien determinasi $\left(R^{2}\right)$ sebesar 0,392 memeberikan makna bahwa variabel kepemimpinan hanya mampu menjelaskan perubahan terhadap variabel semangat kerja sebesar 39,2\%, sedangkan sisanya dijelaskan oleh variabel-variabel lain yang tidak termasuk dalam penelitian ini atau error (e).

2. Hubungan lingkungan kerja fisik $\left(\mathrm{X}_{2}\right)$ dengan semangat kerja $(\mathrm{Y})$

Tabel 6

Analisis Korelasi Variabel $\left(\mathrm{X}_{2}\right)$ dan $(\mathrm{Y})$

\begin{tabular}{|l|l|r|r|r|}
\hline Model & $\mathrm{R}$ & R Square & $\begin{array}{c}\text { Adjusted } \mathrm{R} \\
\text { Square }\end{array}$ & $\begin{array}{c}\text { Std. Error of the } \\
\text { Estimate }\end{array}$ \\
\hline 1 &, $706(\mathrm{a})$ &, 499 &, 488 & 6,466 \\
\hline
\end{tabular}

Berdasarkan hasil hasil perhitungan melalui program SPSS dapat di intepretasikan sebagai berikut :

- Pada Model Summary diperoleh nilai $R=0,706$ yang berarti bahwa hubungan atau tingkat asosiasi variabel bebas yaitu lingkungan kerja fisik dengan variabel terikat yaitu semangat kerja adalah kuat dan memiliki arah yang positif.
- Angka R Square (nilai koefisien determinasi $\left(\mathrm{R}^{2}\right)$ sebesar 0,499 memeberikan makna bahwa variabel lingkungan kerja fisik hanya mampu menjelaskan perubahan terhadap variabel semangat kerja sebesar $49,9 \%$, sedangkan sisanya dijelaskan oleh variabelvariabel lain yang tidak termasuk dalam penelitian ini atau error (e). 
3. Hubungan kepemimpinan $\left(X_{1}\right)$ dan lingkungan kerja fisik $\left(X_{2}\right)$ dengan semangat $\operatorname{kerja~}(\mathrm{Y})$

Tabel 7

Analisis Korelasi Variabel $\left(\mathrm{X}_{1}\right),\left(\mathrm{X}_{2}\right)$ dan $(\mathrm{Y})$

\begin{tabular}{|l|l|r|r|r|}
\hline Model & $\mathrm{R}$ & R Square & $\begin{array}{c}\text { Adjusted R } \\
\text { Square }\end{array}$ & $\begin{array}{c}\text { Std. Error of } \\
\text { the Estimate }\end{array}$ \\
\hline 1 &, $759(\mathrm{a})$ &, 577 &, 559 & 6,006 \\
\hline
\end{tabular}

Berdasarkan hasil perhitungan melalui program SPSS dapat di intepretasikan sebagai berikut :

- Pada Model Summary diperoleh nilai $R=0,759$ yang berarti bahwa hubungan atau tingkat asosiasi variabel bebas yaitu kepemimpinan dan lingkungan kerja fisik dengan variabel terikat yaitu semangat kerja adalah sangat kuat positif.

- Angka R Square (nilai koefisien determinasi $\left(R^{2}\right)$ sebesar 0,577 memeberikan makna bahwa secara simultan atau serentak kedua variabel bebas yaitu variabel kepemimpinan dan lingkungan kerja fisik hanya mampu menjelaskan perubahan terhadap variabel semangat kerja sebesar 57,7\%, sedangkan sisanya dijelaskan oleh variabel-variabel lain yang tidak termasuk dalam penelitian ini atau error (e).

\section{E. PENGUJIAN HIPOTESIS}

Pengujian hipotesis dimaksudkan untuk mengetahui apakah hipotesis penelitian yang diajukan ditolak atau diterima pada tingkat signifikan tertentu. Pada penelitian ini dilakukan analisis regresi untuk mengetahui apakah kedua variabel bebas yaitu kepemimpinan (X1) dan lingkungan kerja fisik $\left(\mathrm{X}_{2}\right)$, secara parsial (sendiri-sendiri) dan secara simultan (bersama-sama) berpengaruh positif terhadap semangat kerja karyawan Universitas PGRI Palembang.

Pengujian untuk mengetahui ada tidaknya pengaruh dari masingmasing variabel bebas dengan variabel terikat secara parsial dilakukan dengan uji-t, sedangkan untuk mengetahui ada tidaknya pengaruh dari variabel bebas dengan variabel terikat secara simultan dilakukan melalui uji-F.

1. Pengaruh kepemimpinan $\left(X_{1}\right)$ dengan semangat kerja (Y)

Dari hasil perhitungan tabel diatas terilihat bahwa pada kolom signifikansi untuk baris kepemimpinan diperoleh 0,005 atau signifikansi yang diperoleh lebih kecil dari $\alpha=0,05$, artinya $\mathrm{H}_{0}$ ditolak, $\mathrm{H}_{\mathrm{a}}$ diterima. Hal ini dapat diartikan terdapat pengaruh yang signifikan antara kepemimpinan dengan semangat kerja karyawan Universitas PGRI Palembang.

2. Pengaruh lingkungan kerja fisik $\left(X_{2}\right)$ dengan semangat kerja $(Y)$

Dari hasil perhitungan tabel diatas terilihat bahwa pada kolom signifikansi untuk baris lingkungan kerja fisik diperoleh 0,000 atau signifikansi yang diperoleh lebih kecil dari $\alpha=0,05$, artinya $\mathrm{H}_{0}$ ditolak, $\mathrm{H}_{\mathrm{a}}$ diterima. Hal ini dapat diartikan terdapat pengaruh yang signifikan antara lingkungan kerja fisik dengan semangat kerja karyawan Universitas PGRI Palembang. 
3. Pengaruh kepemimpinan $\left(X_{1}\right)$ dan lingkungan kerja fisik $\left(X_{2}\right)$ dengan semangat kerja $(Y)$

Dari hasil hasil perhitungan diperoleh nilai taraf signifikansi sebesar 0,000 atau signifikansi yang diperoleh lebih kecil dari $\alpha=$ 0,05 , artinya $\mathrm{H}_{0}$ ditolak, $\mathrm{H}_{\mathrm{a}}$ diterima. Hal ini dapat diartikan terdapat pengaruh yang signifikan antara kepemimpinan dan lingkungan kerja fisik secara bersama-sama dengan semangat kerja karyawan Universitas PGRI Palembang.

\section{KESIMPULAN DAN SARAN}

\section{A. Kesimpulan}

Berdasarkan hasil analisis pengaruh dapat disimpulkan :

1. Bahwa secara parsial terdapat pengaruh yang positif dan signifikan antara kepemimpinan dengan semangat kerja karyawan Universitas PGRI Palembang, artinya apabila ada peningkatan dalam kepemimpinan maka semangat kerja karyawan juga akan meningkat.

2. Secara parsial juga terdapat pengaruh yang positif dan signifikan antara lingkungan kerja fisik dengan semangat kerja karyawan Universitas PGRI Palembang, hal ini mengandung makna bahwa apabila ada peningkatan dalam lingkungan kerja fisik maka semangat kerja karyawan juga akan meningkat.

3. Secara bersama-sama atau simultan terdapat pengaruh yang positif dan signifikan antara kepemimpinan dan lingkungan kerja fisik dengan semangat kerja karyawan Universitas PGRI Palembang, hal ini berarti apabila ada peningkatan dalam kepemimpinan dan lingkungan kerja fisik maka semangat kerja karyawan akan meningkat.

B. Saran

1. Pimpinan lembaga harus memperhatikan lingkungan kerja fisik dengan baik untuk mendukung pekerjaan yang dilaksanakan oleh karyawan, sehingga dapat mendorong semangat kerja karyawan.

2. Disiplin perlu ditingkatkan secara berkesinambungan dengan terus memperketat aturan-aturan terhadap karyawan, sehingga diharapkan dengan disiplin yang tinggi terhadap karyawan akan meningkatkan semangat kerja karyawan secara keseluruhan.

3. Perilaku dan semangat kerja berkaitan erat dengan kepemimpinan dan lingkungan kerja fisik untuk mencapai tujuan organisasi yang efektif dan efisien. Untuk itu diharapkan Universitas PGRI Palembang harus terus memperhatikan kepemimpinan dan lingkungan kerja fisik untuk meningkatkan semangat kerja karyawan.

\section{DAFTAR PUSTAKA}

Ahmad Tohardi, (2002). Manajemen Sumber Daya Manusia, Penerbit CV. Mandar Maju, Bandung.

Alex S. Nitisemito, (2002). Manajemen Personalia. Cetakan Kesembilan, Edisi Ketiga, Penerbit Ghali Indonesia, Jakarta. 
H.B. Siswanto (2006). Pengantar Manajemen. Penerbit Bumi Aksara.

Hadari Nawawi, (2001). Manajemen Sumber Daya Manusia Untuk Bisnis yang Kompetitif, Cetakan Pertama, Penerbit UGM, Yogyakarta.

Haryono, Siswoyo. 2007. Metodologi Penelitian Bisnis. Palembang: MM-UTP 2007. Statistika Penelitian Manajemen dengan program SPSS. Edisi pertama. Jakarta.

Husein Umar, (2006), Riset Sumber Daya Manusia Dalam Organisasi, Edisi Revisi \& Perluasan, Penerbit PT. Gramedia Pustaka Utama.

I Gusti Ngurah Gorda, (2004 \& 2006). Manajemen Sumber Daya Manusia, Penerbit Astabrata Bali, Denpasar.

Kenneth N. Wexley dan Gary A. Yuki, (2003). Perilaku Organisasi dan Psikologi Personalia, Penerbit Rineka Cipta, Jakarta.

Miftah Thoha, (2003). Kepemimpinan Dalam Manajemen Suatu Pendekatan Perilaku, Cetakan Kesembilan, Penerbit PT. Raja Grafindo Persada, Jakarta.

Moekijat, (2002). Manajemen Sumber Daya Manusia (Manajemen

Kepegawaian). Penerbit Mandar Maju, Jakarta.

Moekijat. 2004. Tata Laksana Kantor Manajemen Perkantoran. Cetakan ke-8. Bandung : CV. Mandar Maju.

Rivai, Veithzal. 2004. Kepemimpinan dan Perilaku Organisasi. Edisi 2. Jakarta: PT. Rajagrafindo Persada.
Sondang P. Siagian, (2002). Manajemen Sumber Daya Manusia, Penerbit Bumi Aksara, Jakarta.

Sugiyono, (2002). Metode Penelitian Bisnis. Penerbit Alfabeta, Bandung.

Sugiyono. 2008. Metode Penelitian Bisnis (Pendekatan Kuantitatif, Kualitatif dan $R \& D$ ). Bandung : Alfabeta. 2005. Statistik untuk Penelitian. Cetakan ke delapan, Bandung : Alfabeta.

Sunyoto, Danang. 2007. Analisis Regresi dan Korelasi Bivariat. Yogyakarta : Amara Books.

Supardi dan Syaiful Anwar, (2002). Dasar-dasar Perilaku Organisasi, Penerbit UII Press, Yogyakarta.

T. Hani Handoko, (2000). Manajemen, Edisi 2, Penerbit BPFE, Yogyakarta. 